\title{
A VIDÉK ÚJRASTRUKTURÁLÓDÁSA ÉS A PREKARIÁTUS FOGALMA A MAJOROK KUTATÁSÁNAK SZEMSZÖGÉBŐL
}

\author{
MIKLE GYÖRGY \\ RURAL RESTRUCTURING AND THE PRECARIAT FROM THE VIEWPOINT OF \\ MANORIAL SETTLEMENTS
}

\begin{abstract}
In pre-World War II Hungary the countryside was dominated by large estates. Estates built manors (puszta or major) at the centre of their agricultural territory, usually on the outskirts of neighbouring communities. After World War II, state farms and co-operatives became stakeholders in most of the manors. These companies were privatised or abolished after 1990, resulting in high unemployment rates on the local scale. These processes have already been studied by a number of scholars; what this paper aims to do is revisit the available results in light of two concepts: the precariat and rural restructuring. My argument is that these concepts might add new viewpoints to the interpretation of processes on the local scale by placing them in national and international contexts. The precariat seems to be present throughout the whole twentieth century in these settlements, with working and living conditions dependent on the stakeholders. If we approach the concept from the viewpoint of world systems theory, it can be seen that both the large estates before WWII and the state socialist agricultural companies after were strictly connected to international markets, which made life even more precarious in manors. Rural restructuring can be defined as the transformation of three spheres: the state, the economic system, and civil society. Looking at these processes throughout the twentieth century, it is evident that manors underwent restructuring in the second half of the state socialist period, with a more radical transformation beginning in the 1990s.
\end{abstract}

Keywords: manors, rural restructuring, precariat

\section{Bevezetés}

A hazai nagybirtokokhoz kapcsolódó településforma, az uradalmi major vagy puszta kutatása több tudományterület képviselőinek érdeklődését felkeltette. A társadalomföldrajzos szerzők (Mendöl T. 1963; Beluszky P. 1999; BAJMÓcy P. et al. 2008; BALOGH A.-BAjmócy P. 2011; Bajmócy P.-BALOgh A. 2012; Horváth Cs. 2015), építészetszociológusok (TAMÁSKA M. 2013) elsősorban a majorok morfológiai jellegzetességeit, településhálózati pozícióját és funkcióit vizsgálták. Az uradalmi cselédség helyzetével népi írók (ILlyés Gy. 1936; FÉJA G. 1938; ERDEI F. 1940), néprajzos kutatók (KARDOS L. 1955; EPERJESSY E. 2006), illetve társadalomtörténész szakemberek (GuNST P. 1998; GYÁNI G.-KöVÉR GY.2004) foglalkoztak részletesebben. A szocialista nagyüzemi mezőgazdaság és a rendszerváltást követő privatizáció helyi társadalomra gyakorolt hatásait főleg szociológusok (MÁTyus A.-TAusz K. 1984; Kovács É.-VIDRA Zs. 2012; Vigvári A. 2015; VIRÁG T. 2015; NÉMETH K. 2013, 2015, 2016) kutatták.

A majorokat alakító társadalmi-gazdasági átmenetek tekintetében három korszak elkülönítése jellemző, amelyek a második világháború előtti uradalmi múlt, a szocialista nagyüzemi időszak, majd az ezt követő privatizáció. Amint az több tanulmányban is tetten érhetô, a majorok helyi társadalmát alakító tényezők közül fontos a tulajdonviszonyok, kezelői-fenntartói szerepkörök alakulása, vagyis annak a keretrendszernek a vizsgálata, amelybe a majorok a különböző korszakokban beágyazódtak. Tanulmányomban a majorok 
kutatásának ezt az aspektusát szeretném kidomborítani: a különböző - a helyitől a globálisig terjedő - földrajzi léptékeken zajló folyamatok kapcsolatára, illetve ennek a kérdésnek a kutatására, kutathatóságára fókuszálok. Az elemzésben csak részben építek a majorokkal foglalkozó irodalomra, a további szakirodalmi bázist két nyugati társadalomelméleti vitakérdéshez kapcsolódó munkák adják. A dolgozat így három kérdéskör szakmai írásainak összeolvasásán alapul: ezek a majorok kutatási előzményei mellett a vidék újrastrukturálódásával, illetve a prekariátussal foglalkozó munkák.

A vidék újrastrukturálódásának (rural restructuring) vizsgálata a nyugati, elsősorban angolszász társadalomföldrajzban nagyjából három évtizedes múltra tekint vissza, így hangsúlyai többször változtak. KeITH HogGART és ANGEL PANIAGUA 2001-ben két tanulmányban is hozzájárult a témakör kutatásához (HogGART, K.-PANIAGUA, A. 2001a, 2001b). Mindkét írásban a fogalom képlékeny használata miatt bírálták a korábbi szerzőket, ugyanakkor az újrastrukturálódást egy olyan komplex átalakulásként definiálták, amelynek három elemét különböztették meg: ezek az állam szerepének változása, a gazdasági környezet átalakulása, illetve a civil társadalom átalakulása. Tanulmányomban az újrastrukturálódással kapcsolatban arra a kérdésre keresem a választ, hogy milyen következtetésekre juthatnánk, ha a majorok elmúlt száz évben végbement átalakulását ezek mentén a dimenziók mentén vizsgálnánk: hogyan csapódtak le az országos léptéken zajló struktúraváltások ezeken a helyeken, zajlott-e érdemi újrastrukturálódás, és ha igen, mikor, minek hatására és milyen közvetítő mechanizmusokon keresztül, más szóval hogyan viszonyul egymáshoz a változás és az állandóság ezeken a településeken?

A bizonytalan munkaerőpiaci helyzetet és az ebből következő létbizonytalanságot jelentő prekaritás (precarity), valamint az ilyen helyzetben lévő egyéneket jelölő prekariátus (precariat) fogalma nemzetközi szinten is viszonylag új, azonban az utóbbi években a hazai társadalomtudományban is megjelent a használatuk, illetve többen vizsgálták a fogalmak adaptálhatóságát is (BöCSKEI B.-SzÉPE A. 2012; Fordulat 2012; SzÉPE A. 2012; KELEMEN Zs.-RAKOviCs M. 2013; FARKAS X. 2015; ÉBER M. Á. 2016). A legnagyobb lélegzetvételú magyar nyelvú munka SzÉPE ANDRÁs doktori értekezése (SzÉPE A. 2016), aki a függőségi és világrendszer-elméletek szempontjából értelmezte a fogalmat, amely szemléletmód szintén az utóbbi évtizedben kapott kiemelt figyelmet a hazai társadalomtudósok körében (lásd például ÉBER, M. Á. 2014; ÉBER M. Á. et al. 2014; ÉBER M. Á. 2015; PINKASZ A.-GERőCs T. 2017; ÉBER M. Á. 2018; PÓSFAI Zs. 2018). A függőségi és világrendszer-elméletek a kapitalista világgazdaságot hierarchikus rendszerként értelmezik, amelynek múködése földrajzilag is jól lehatárolható centrum - félperiféria - periféria viszonyokat eredményez, jobban mondva ez a viszony teszi lehetôvé a világgazdaság múködését. Ebben a viszonyrendszerben Magyarország félperifériás helyet foglal el, amely egy függő pozíció. Jómagam amellett érvelek, hogy az értekezésben kifejtett gondolatmenet - amely szerint a globális függőségi rendszerekhez füződő viszony meghatározó tényező a bizonytalan élethelyzetek létrehozásában - a majorok történeti távlatú vizsgálata során is hasznosítható. Ennek kapcsán a következő kérdésekre koncentrálok: miként alakult a majorokat üzemeltető-kezelő szereplők beágyazottsága a nemzetközi, globális gazdaságba a 20. század elejétôl napjainkig, mennyire függ a helyi társadalom helyzete az ott zajló trendektől?

Tanulmányomban eltekintek a hivatkozott témakörök kutatási előzményeinek részletes ismertetésétől, inkább Hoggart, K. és PaniaguA, A. (2001a, 2001b), valamint SzÉPE A. (2016) érvelésére, valamint az ezek szempontjából fontos forrásokra koncentrálok. A szerzők gondolatmenetét a majorokhoz köthető szakirodalom tükrében elemzem, így külön „szembesítem” az újrastrukturálódás, majd a prekariátus témakörét a majorokra vonatkozó eredményekkel. A tanulmányban közvetlenül nem építek saját empirikus kutatásra - bár közvetve sokat merítek korábbi terepi tapasztalatokból, és levéltári kutatásból is, amely 
földrajzilag a mai Komárom-Esztergom megye majorjainak vizsgálatát, valamint Bábolna és Mezőhegyes majorjainak összehasonlítását jelentette (lásd: MikLE Gy. 2015) - inkább célom a majorokról rendelkezésre álló ismeretek új szempontú értelmezése. Ez reményeim szerint azon túl, hogy a majorokban a 20. század folyamán helyi szinten megfigyelhető élet- és munkakörülményeket országos és globális kontextusba helyezi, illetve az ezeken a léptékeken zajló folyamatokkal magyarázza, az újrastrukturálódás és a prekariátus témakörét is új szempontokkal egészítheti ki.

\section{Újrastrukturálódás}

A vidék újrastrukturálódásának fogalma a politikai gazdaságtani perspektíva térnyerésével jelent meg a vidékkel foglalkozó kutatók körében, amely a brit vidékföldrajzban az 1980-as évekre tehető (Cloke, P. 1989; WoOds, M. 2005, 2009; KovÁch I. 2012). A szemléletmód főleg neomarxista szerzőkhöz köthető, akik a társadalmi folyamatokat a hatalmi viszonyok, a kapitalista termelési mód jellemzőinek függvényében elemezték. A vidéki újrastrukturálódás vizsgálata során így kiemelt figyelmet szenteltek az osztályviszonyok átalakulásának. Ez tetten érhető például olyan témák kutatásánál, mint a mezőgazdasági termeléssel foglalkozó népesség helyzete (MARSDEN, T. et al. 1986), a városokból a vidéki térségbe irányuló migráció, az ellenurbanizáció (CLOKE, P. - THRIFT, N. 1987), vagy a gazdasági szerkezetváltás (THRIFT, N. 1987). Módszertanilag társadalmi makrostruktúrák statisztikáinak elemzése volt jellemző, így az országos, regionális léptékek olyan mutatóit vizsgálták, amelyek a társadalom szerkezetének változására utalhatnak (például a foglalkoztatottság szektorális jellemzői, tulajdonviszonyok átalakulása, migráció).

Keith Hoggart és Angel Paniagua (2001a, 2001b) két tanulmánya ehhez, az 1980-as évektől meginduló, többször hangsúlyt változtató tudományos párbeszédhez szól hozzá. A szerzópáros arra hívja fel a figyelmet, hogy a szerzők egy jelentős része az újrastrukturálódás fogalmát helytelenül használta, és gyakran alkalmazták a fogalmat olyan átalakulások megnevezésére is, mint például egy politikai, vagy egy gazdaságszervezési irányváltás. Álláspontjuk szerint a fogalom egy összetett, több dimenzió mentén megvalósuló átalakulást jelöl, amely során az állam szerepe, a gazdasági környezet, illetve a civil társadalom egyaránt megváltozik. Ezeket a szempontokat két, a '90-es években megjelent tanulmány alapján jelölik ki (CloKe, P.-GoodwIN, M. 1992; MARSDEN, T. 1996), amelyek a vidéki terek átalakulásának vizsgálatakor a komplex szemléletmód alkalmazása mellett érveltek. Tanulmányomban erre a három dimenzióra fókuszálok, ugyanakkor igyekszem a majorok vizsgálata során fellépó sajátosságok szerint finomítani a koncepciót. Az egyik ilyen jellegzetesség, hogy a rendelkezésre álló statisztikai adatok meglehetôsen szúkösek, és nehezen követhető az egyes mutatók változása. A népességszám az egyetlen jellemző, amely a 20. század elejétôl folyamatosan vizsgálható, a népesség egyéb jellemzői néhány népszámlálástól eltekintve általában nem érhetóek el az egyes majorok szintjén. További probléma, hogy a Központi Statisztikai Hivatal funkcionális alapon kategorizálja a külterületi lakott helyeket, így a hivatalos statisztika nem különbözteti meg önálló kategóriaként a majorokat, pusztákat. Mindezek következtében a jelen elemzésben felhasznált források a vonatkozó szakirodalomra korlátozódnak, ami ugyan eltér az újrastrukturálódással foglalkozó tanulmányok módszertanától, azonban a legfontosabb folyamatokról így is átfogó képet kaphatunk. A Hoggart és PANiAgua (2001a, 2001b) által civil társadalomnak nevezett dimenziót helyi társadalomként fogom használni. Ezt indokolja egyrészt, hogy a helyi léptéken tapasztalható változásokra koncentrálok, másrészt a majorok társadalmát történelmi távlatban - a gazdasági szereplőktől, valamint az államtól való - nagyfokú függés jellemzi. 


\section{Az állam szerepe}

A majorokra vonatkozó irodalomból kitűnik, hogy sok szerző tüntet fel bizonyos politikatörténeti eseményeket a helyi társadalmak szempontjából fontos szakaszhatárként - jelen tanulmányban is tetten érhető ez a fajta logika. Ezekhez az időpontokhoz (az 1945-ös földosztás, az 1948-as kommunista hatalomátvétel, az 1989-ben megindult rendszerváltás) a fenti három dimenzió szempontjából elsősorban az állam szerepének változása köthetô. Ez a felosztás általánosan, nem csupán a majorok kontextusában jellemzi a hazai társadalomtörténeti munkákat, hiszen a második világháború után a szovjet érdekszférába kerülés, majd az 1980-as évek végén a nyugati minták nyílt átvétele kétségkívül jelentős ideológiai változásokkal jártak, a megelőző időszakokkal több szempontból is szembehelyezkedő felfogást propagáltak. A második világháborút követően az első nagy volumenú intézkedés, amely az állam szerepére mutat rá, az 1945-ös földosztás volt, ami sok major esetében a teljes elnéptelenedéssel járt együtt (BELuszKY P. 1999; BAJMóCY P. et al. 2008; BALogh A.-BAJMócy P. 2011; BAJMócy P.-BALOgh A. 2012). 1948-tól, a Magyar Dolgozók Pártjának hatalomra kerülésével megkezdődött a mezőgazdaság szovjet minták szerinti átalakítása, amely termelőszövetkezetek és állami gazdaságok szervezését jelentette. A majorokban ezek az agrárüzemek váltak - gyakran az egyedüli - munkaadóvá, illetve a helyi folyamatok legfontosabb alakítóivá.

Az 1949 és 1954 közötti időszak a külterületekre vonatkozó állami szabályozás szempontjából emblematikus, csakúgy, mint a szabályozást végrehajtani hivatott Tanyai Tanács múködése. A szervezetet azzal a céllal hozták létre, hogy a külterületi lakott helyek, elsősorban a tanyák népességét az arra kijelölt településekre, úgynevezett tanyaközpontokba telepítse, illetve ösztönözze az érintett népesség átköltözését. Ezzel együtt járt a lakhatáshoz kapcsolódó építkezések tilalma a külterületeken. A Tanács által végrehajtott tanyaközpont-kijelölések végül csak kismértékben érintették a majorokat, ráadásul a Tanácsot 1954-ben fel is oszlatták, majd ezt követően a külterületi építkezések tilalmát is részben feloldották, így a termelőszövetkezetek, illetve állami gazdaságok által kezelt telephelyeken - mint a majorok nagy része - is lehetővé vált a lakások felújítása, esetenként újak építése (HAJDú Z. 1990/1991). A településhálózat fejlesztésének állami szabályozása az ezt követő évtizedekben is alapvetően kistelepülés-ellenes volt, bár főleg az 1960-as évektől sokkal szelídebbé vált a továbbra is a koncentrációt célzó fejlesztéspolitika (HAJDÚ Z. 1992; GYŐRI R.-GYURIS F. 2015)

Az új rendszerek kiépülésével együtt járt a közigazgatás átalakítása, amelyet HoGGART, K. és PAniaguA, A. (2001a, 2001b) az állam átalakulásának egyik formájaként jellemez. A Párt akaratának alávetett tanácsok megszervezése, majd az autonóm önkormányzatiság kialakítása a majorok szempontjából némileg más következményekkel jártak, mint a községek és a városok esetében. Több szerző eredményei is arra mutatnak rá, hogy a települési tanácsok valójában csak formális fennhatósággal bírtak a közigazgatási területükön található majorokban, tényleges jelentősége az őket kezelő szocialista agrárüzemek hozzájuk füződő viszonyának volt. Azon túl, hogy az állami gazdaságok, illetve termelőszövetkezetek biztosították a helyi munkalehetőséget, az infrastruktúra, a lakásállomány, sok esetben a közmúvek fenntartói is ezek a vállalatok voltak a rendszerváltásig (VARGA D. 1991; KovÁcs É.-Vidra Zs. 2012; TAMÁsKA M. 2013; NÉMETH K. 2015, 2016). Ez a korábbi, uradalmi időszakkal összehasonlítva a majorok erőteljes függőségének fennmaradását mutatja, hiszen az akkori mezőgazdasági cselédség élet- és munkakörülményeit döntő részben az ôket alkalmazó uradalom, az uradalom birtokosa alakította.

Az 1990-es évektől a települési önkormányzatok létrehozása, illetve a szocialista agrárüzemek privatizációja a majorokban gyakran tisztázatlan viszonyokat eredményezett a helyi 
közszolgáltatások fenntartása tekintetében (KovÁCs É.-VIDRA Zs. 2012; VASÁRUS G. 2016), hiszen esetenként olyan infrastrukturális elemek is magánkézbe kerültek, amelyek eredetileg a majorban lakókat szolgálták ki (például utak, ivóvízellátást biztosító kutak), az új tulajdonosnak pedig nem érdeke ezeknek a múködtetése, fenntartása. A majorokban található szolgálati lakásokat zömében a lakók vásárolták meg. A majorok többségében ez egy alapvetően új helyzetet eredményezett, hiszen az uradalmi időszakban a cselédlakások a nagybirtok, a szocialista nagyüzemi időszakban a szolgálati lakások az agrárüzem tulajdonát képezték. Az újfajta közigazgatási szabályozással az önkormányzatok döntésén múlik, hogy a települések mely részeit minősítik bel-, illetve külterületnek; a majorok nagyobb része ma külterületi lakott hely, míg kisebb részük egyéb belterület (BALOGH A. 2012; BAJMÓCY P.-MAKRA Zs. 2016; BAJMÓCY P. et al. 2018). A jogi szabályozás értelmében a belterületek minősülnek lakóterületnek, a külterületek nem lakófunkciójú, zömében mezőgazdasági, vagy ipari területek. Mivel a külterületi lakott helyeken az önkormányzatok számára nem kötelező azoknak a közfeladatoknak az ellátása, amely a belterületen igen, így javarészt az önkormányzatok lehetőségeitől és szándékától függ, hogy milyen a külterületi majorok infrastrukturális ellátottsága, illetve az infrastrukturális elemek állapota. Vagyis amíg a községek és városok esetében az önálló önkormányzatiság autonómiát eredményezett, addig a majorokban ez a korábban is jellemző függőség fennmaradásával járt (TiMÁr J. 2016).

\section{A gazdasági környezet átalakulása}

A vidék újrastrukturálódásának elemzése során a gazdasági szerkezetváltás kiemelt figyelmet kapott a kérdéssel foglalkozók körében. A nyugati neomarxista szerzők például olyan jelenségeket vizsgáltak, mint az 1970-es évek város-vidék gyáripari átmenete, különös tekintettel a folyamat strukturális hátterére (THRIFT, N. 1987). Az elmúlt száz évben Magyarországon is jelentősen megváltozott a vidék gazdasági arculata, több gazdaságszervezési irányváltás is megvalósult ebben az időszakban. A majorok kiépülése, és cselédekkel történő benépesítése a 19. század második felétől, a kapitalista termelési viszonyok megszilárdulásával gyorsult fel.Ezek a települések az nagybirtokok termelési és igazgatási központjai voltak, ahol a nagyobb uradalmak esetén a mezőgazdasági termelés mellett feldolgozóipari tevékenységek is zajlottak, a helyi népesség azonban főleg az agrártársadalomhoz tartozott. A majorokban a szocialista nagyüzemi mezőgazdaság kiépülése bizonyos szempontból a korábbi struktúrák fennmaradásával járt együtt, különösen ott, ahol az uradalmak helyét állami gazdaságok vették át. A kontinuitás például az üzemszervezés tekintetében, vagy bizonyos munkaköröknek, az azokhoz kapcsolt értékeknek az uradalmi időszakból való átöröklődésében nyilvánult meg (CsoóRI S. 1963). A mezőgazdasági termelés dominanciája is fennmaradt, valamint az a jellegzetessége, hogy a termelés az országos, illetve nemzetközi piacokat célozta, nem a majorokhoz közeli városokat, vagy falvakat (MENDöL T. 1963; JuHÁsz P. 2006).

A gazdálkodás technológiai környezete ugyanakkor jelentősen átalakult, különösen az 1960-as évek második felétől, az iparszerú termelési rendszerek kialakításával. Az újfajta termelésszervezés miatt az állami gazdaságok vezetői nagy hangsúlyt fektettek a gépesített, korszerú gazdálkodásra, így a gazdálkodás jellege, a konkrét munkafolyamatok, valamint az üzemek munkaeróigénye is megváltozott. A termelésszervezési reformok az országos léptéken bekövetkezett irányváltás következményei voltak, amire az erőszakos kollektivizálás által a mezőgazdasági termelésben, valamint az agrártársadalomban okozott károk miatt is szükség volt. Bár az állami gazdaságok kiépülése már az 1950-es évekre megtörtént, a reformok ezt a szervezeti formát is érintették. A legfontosabb újítások 
a korábbi politikai-ideológiai alapú döntéshozatallal szemben a vezetők szakmai alapon történő kiválasztása, a vállalati döntések önállósítása, valamint az állami gazdaságok összevonása, koncentrációja voltak (IZINGER P. 1983; MoLNÁR I.-SZABÓNÉ MEDGYESI É. 1987; KLENCZNER A. 1996; VARGA Zs. 2011). A termelőszövetkezetekben a reformok hatására az állami gazdaságokhoz hasonló munkaszervezési elvek (például kötött munkakörök és munkaidő) valósultak meg, amely az ipari munkahelyeken a fordizmussal elterjedő, modernista termelésszervezést jelentett, és a korábban jellemző paraszti gazdálkodás eltûnésével járt együtt (Lengyel Zs. 1981; ERdei F. 1984; Hann, C. 2003; LAMPLAND, M. 2016). A gazdasági szerkezetváltás egyik jelenségeként értelmezhető a termelőszövetkezeti tagság körében a háztáji gazdálkodásra, vagyis a második gazdaságra alapozott többletjövedelem megjelenése, illetve általánossá válása is (JuHÁsz P. 1999). Ezt a fajta jövedelemszerzési stratégiát ugyanakkor a majorokban élők nem minden esetben vették át, így anyagi helyzetük jóval nagyobb mértékben függött az őket alkalmazó nagyüzemtől (NÉMETH K. 2016).

HogGart, K. és PANiagua, A. (2001a, 2001b), valamint más szerzők is a gazdasági termelés szektorális átmeneteit definiálták az újrastrukturálódás egyik jegyeként. A hazai falvak esetében az államszocializmus évtizedei komolyabb nyomot hagytak a gazdasági szektorok jelenlétén, mivel a vidéki térségekbe irányuló ipartelepítések mellett a termelőszövetkezetek melléküzemági - zömmel élelmiszeripari, könnyúipari - tevékenysége is jelentősen csökkentette az agrárszektor súlyát. A majorok esetében általánosan a korábbi, mezőgazdasági termelés fennmaradása volt jellemző. Azokban a majorokban, ahol a népesség a rendszerváltásig tartósan megmaradt, általában állattartó telepek, vagy termelőszövetkezeti központok múködtek. Amíg a rendszerváltást követően a termelőszövetkezeti rendszert szinte azonnal megszüntették, az állami gazdaságok privatizációja lassabb, többlépcsős folyamat volt. Ennek következtében a majorok többségében csak az 1990-es évek második, a 2000-es évek első felében szűntek meg teljesen a korábbi keretek (KlenCZNER A. 1996; VARGA Zs. 2011). Az állami gazdasági telephelyek privatizációját követően a majorokban esetenként tovább folyhatott a termelés, azonban a magánkézbe került üzemek a majorban élőknek általában már nem, vagy csak kis számban alkalmazták. Vagyis amíg a vidéki térségek zömében már a szocializmus évtizedeiben megkezdődött egyfajta gazdasági szerkezetváltás, a legtöbb major esetében ez nagyobb mértékben csak a rendszerváltás után jelentkezett.

\section{A helyi társadalom átalakulása}

A helyi társadalmak átalakulását az 1980-as évek brit vidékkutatói az osztályszerkezet átalakulásával azonosították. Ennek okát a helyi gazdaság szerkezetváltásában, illetve az ellenurbanizáció folyamatában látták, amelynek következtében új, a vidéki közösségekétôl eltérő hátterú népesség áramlott ezekre a területekre (CloKe, P. 1989). HogGART, K. és PAniagua, A. (2001a, 2001b) is rámutatott, hogy a vidéki népesség foglalkozási szerkezetének átalakulása és a népességmozgások az újrastrukturálódás indikátorai, emellett arra hívták fel a figyelmet, hogy téves az általános, az egész társadalomban végbemenő modernizációs folyamatok vidéki megjelenését az újrastrukturálódással azonosítani. A szerzőpáros amellett érvelt, hogy fontos szem előtt tartani, hogy a vidéki terek mennyiben jelentenek minőségileg egyedi közeget, és hogy ennek milyen szintú és irányú átalakulása tapasztalható több évtized, vagy egy évszázad távlatában.

A majorok esetén a jobbágyfelszabadítástól a földosztásig terjedô időszakban a cselédség képezte a helyi társadalom alapját, amely a korabeli agrárnépesség egyik legkiszolgáltatottabb, legkevésbé megbecsült csoportja volt (ILlYÉs GY. 1936; FÉJA G. 1938; BEREND T. I.-RÁNKI GY. 1976; EPERJESSY E. 2006). Általánosan elmondható, hogy a kö- 
zeli falvaktól és városoktól elszigetelten éltek, a mindennapokban nem érintkeztek a környező településeken élőkkel, ami már csak a szoros munkarend miatt sem lett volna lehetséges. Társadalmuk ugyanakkor meglehetôsen tagolt volt, mivel az uradalmakban elvégzendő munka nagyfokú specializációt kívánt, különösen az állattartáshoz kapcsolódó munkafázisok miatt (EPERJESSY E. 2006; LAMPLAND, M. 2016). 1945 után az uradalmak felbomlásával a cselédség is megszúnt, de még egy bő évtizedig az uradalmakban kialakult mentalitás jellemezte az állami gazdaságok belső munkamegosztását (CSOÓRI S. 1963; IZINGER P. 1981; JUHÁsz P. 2006). A szocialista nagyüzemi gazdálkodás megszilárdulásának időszaka a vidéki terekben a parasztság felszámolását jelentette, a majorokban némileg más jellegú változásokkal járt együtt. Az egykori cselédekből állami gazdasági dolgozók, illetve termelőszövetkezeti tagok lettek. Mindkét státuszról elmondható, hogy az 1960-as években lezajlott reformintézkedéseket követően a szociális jogok fokozatos bővülése figyelhetô meg körükben, így a társadalombiztosítási rendszer egyre több eleme terjedt ki rájuk, valamint a két csoportba tartozók egymáshoz viszonyított helyzete is egyre kevésbé különbözött (ERDEI F. 1984). Az állami gazdaságokban dolgozó, illetve termelőszövetkezetek tagságát alkotó egykori cselédek számára az alkalmazotti viszony és az ezzel együtt járó életmód, valamint a munka- és életkörülmények tekintetében megnyilvánuló nagyfokú függóség önmagában nem jelentett újdonságot (SIK E.-TAUSZ K. 1987; NÉMETH K. 2013, 2015, 2016). Más szóval a helyi társadalomnak a környezetéhez fúződő viszonya ebben az értelemben kontinuusnak tekinthető, miközben az országos léptéken végbemenő társadalmi változások (a társadalmi ellátórendszer bővülése, a lakhatási viszonyok javulása, a közlekedés, az elérhetôség javulása) a majorokban is jelentkeztek, és sok helyen a zártság oldódásával jártak együtt. Az 1980-as évek végén megindult rendszerváltás, és az azt követő gazdasági átmenet markáns változásokat eredményezett a majorok társadalmában. Országos léptéken, és a legtöbb vidéki térségben a mezőgazdaságban foglalkoztatott népesség drasztikus csökkenése volt jellemző az állami gazdaságok és termelőszövetkezetek felbomlásának következtében. A majorok esetén ez azért volt különösen problematikus, mivel az agrárvállalatok megszúnése gyakran a helyi munkalehetőségek teljes megszúnésével járt. Ennek következménye, hogy a majorokban élők között ma sok a bizonytalan munkaerőpiaci helyzetú, közmunkában foglalkoztatott ember, illetve gyakori az alkalmi, valamint illegális munkavállalás (KovÁcs É.-VIDRA Zs. 2012, VIRÁG T. 2015; NÉMETH K. 2016; VASÁRUS G. 2016).

A majorokat érintő népességmozgások közül az uradalmi időszakban a szezonális munkások (summások) időszakos jelenléte volt a legfontosabb, általánosan elterjedt jelenség. A második világháború előtti időszakra fókuszáló írások alapján a cselédek migrációja főként majorok, uradalmak között zajlott, így a majorok társadalmát általában nem alakította át más hátterú népesség betelepülése (ILLYÉs GY. 1936; EPERJESSY E. 2006; TAMÁSKA M. 2013). A második világháborút követôen a földosztással sok majorban egy jelentős elvándorlási hullám jelentkezett, az uradalmak felbomlásával a majorok egy része teljesen elnéptelenedett. A továbbra is lakott majorokban az új, nagyüzemi keretek megszilárdulása esetenként ugyan képes volt stabilizálni a népességet, azonban országosan a majorokban élők számának folyamatos és jelentős csökkenése mutatkozott a rendszerváltásig, különösen az 1970-es évektől (BALOGH A.-BAJMÓcy P. 2014; BAJMÓcy P.-MAKRA Zs. 2016; BALOGH A. 2016; BAJMÓCY P. et al. 2018; MASINKA K. 2018). A majorokba az államszocializmus idején betelepülő népesség létszámára, hátterére vonatkozóan nem rendelkezünk statisztikai adatokkal, azonban több forrás is utal rá, hogy a közeli falvakba beköltözni vágyó, de megfelelő anyagi háttérrel nem rendelkező emberek zömmel valamely majorba költöztek be azzal a céllal, hogy késóbb a belterületre tudjanak költözni. Ez gyakran jelentett az ország rosszabb helyzetű agrárvidékeiről valamely iparosodottabb országrészbe, fóként 
a Dunántúlra történő költözést (kvázi a „kelet-nyugat lejtőn” való felkapaszkodást), amely akár egy községből történő külterületre költözés is lehetett (a „települési lejtőn” történő lecsúszás). A majoroknak ezt a településhálózati pozícióját KovÁcs ÉVA és VIDRA ZsUZSANNA (2012) egy zsilip metaforájával jellemezte, amely a közeli falvakba igyekvő népességet egy időre feltartja, majd fokozatosan engedi be a belterületre. A rendszerváltást követően a majorok fokozódó szelektív elnéptelenedése mellett megfigyelhető, hogy egyre inkább a környező, vagy akár távolabbi települések belterületeiről kiszoruló emberek lakhelyévé válnak, ami fóként a tartósan alacsony ingatlanárakra vezethetô vissza, vagyis az egykori nagyüzemi dolgozók mellett egyre nagyobb arányban van jelen újonnan betelepülő, zömmel alacsonyabb státuszú népesség (VIRÁG T. 2015; NÉmETH K. 2016; VASÁrus G. 2016; CzIRFusz M. et al. 2018). A rendszerváltás után megjelenő ellenurbanizáció, illetve felerôsödő szuburbanizáció bizonyos külterületi lakott helyeket is érintenek, így a külterületek népességszáma az 1990-es évek óta növekedésnek indult az országos léptéken, azonban a majorok népességszáma országosan tovább csökken (1.ábra) (BALOGH A.-BAJMócY P. 2014; BAJMÓCY P.-MAKRA Zs. 2016; BAJMÓCY P. et al. 2018).

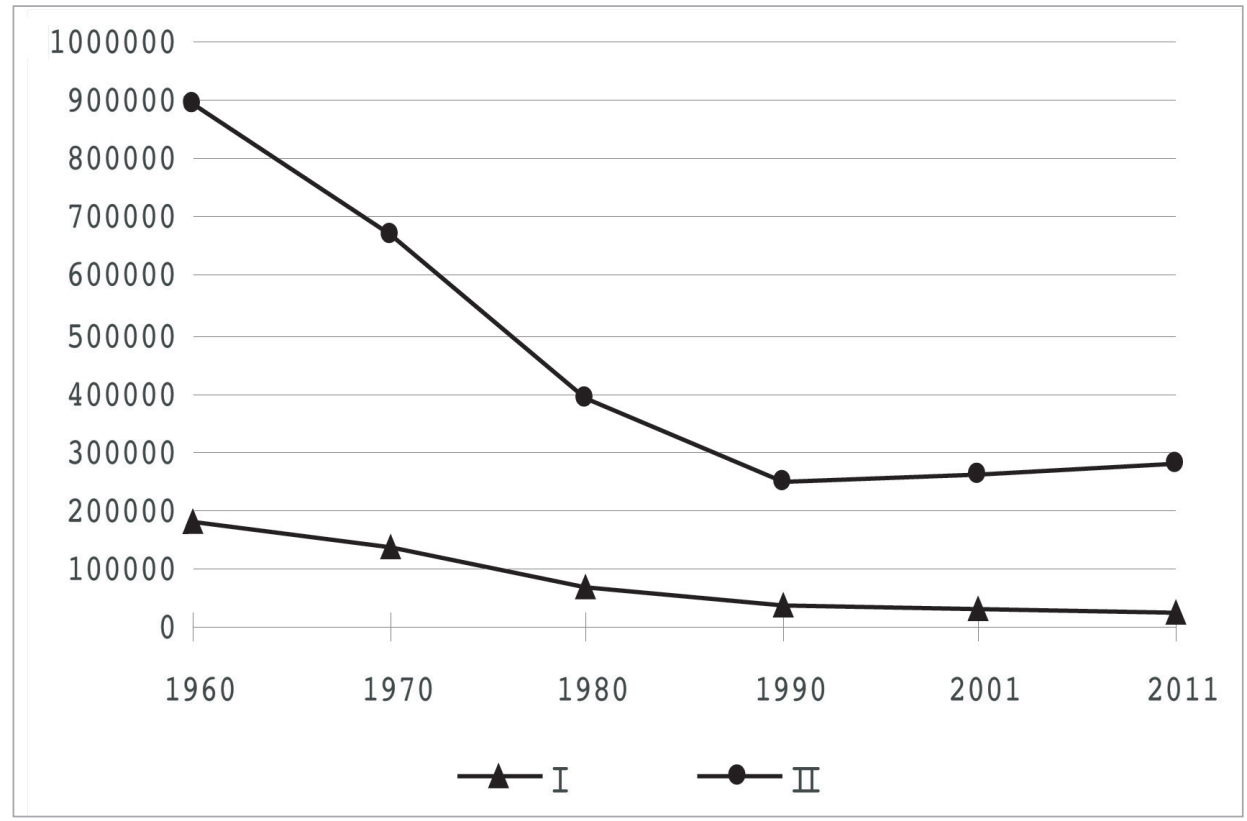

1. ábra A majorok és a többi külterület népességszámának változása Magyarországon (1960-2011) Jelmagyarázat: I. Major/TSZ, II. Többi külterület

Forrás: BAJMócy P.-MAKRA Zs. 2016; BAJMÓcy P. et al. 2018 alapján saját szerkesztés

Figure 1 Number of population at manors and other outskirt settlements in Hungary (1960-2011)

Legend: I. Manor/Cooperative farm, II. Other outskirt settlements

Source: based on BAJMÓCY P.-MAKRA Zs. 2016; BAJMÓCY P. et al. 2018

\section{A prekariátus}

A nyugati társadalomtudományi diskurzusban több ponton is konszenzus uralkodik a prekaritás fogalmának meghatározása, és az azt előidéző okok, folyamatok lehatárolása tekintetében. A kutatók álláspontja egyezik abban, hogy az 1970-es évek második felének 
neoliberális fordulatával, a jóléti államok leépülésével a munka jellege is megváltozott. A munkaerópiaci helyzet egyre bizonytalanabbá vált, és válik, megjelentek a különböző rugalmas foglalkoztatási módok, valamint korábban a munkaviszonyhoz kapcsolt szociális jogok is elvesztek (lásd például: WACQUANT, L. 2011; LAVAQUE-MANTY, M. 2012; Standing, G. 2012; Czirfusz M. 2017; Nagy E. 2017; Siskáné Szilasi B.-Halász L. 2017). Kevésbé egységes azonban az ilyen helyzetbe került egyének, a prekariátus lehatárolása, illetve a fogalom globális, a nyugati világon (az egykori jóléti államokon) kívüli relevanciájának megítélése. A témakör kutatásához az utóbbi években több magyar kutató is hozzájárult, akik ez utóbbi kettő szempontra is kitértek: értelmezhető-e a prekariátus Magyarországon, ha igen, kik tartoznak ebbe a csoportba (BÖCSKEI B.-SzÉPE A. 2012; Fordulat 2012; SzÉPE A. 2012; KELEMEN Zs.-RAKOVICS M. 2013; FARKAS X. 2015; ÉBER M. Á. 2016)?

A legnagyobb bizonytalanságot az okozza, hogy hazánknak nem volt a nyugati kutatók által referenciapontként használt jóléti állami időszaka. Ennek feloldására SzÉPE ANDRÁs (2016) a függőségi és világrendszer-elméletek szemszögéből vizsgálta a prekaritást.Érvelése szerint a kapitalizmus globális története során a prekaritás tekinthető normának, és a földrajzilag (Észak-Amerika, Észak-, illetve Nyugat-Európa) és történelmileg (nagyjából három évtized) is csak korlátoltan megvalósuló jóléti államok képezik a kivételt. A centrumtérségeken kívüli társadalmak globális gazdasággal fennálló kapcsolatának intenzitása ugyanakkor egyenes arányban áll a munka bizonytalanságával. Ennek oka SzÉPE ANDRÁs (2016) szerint, hogy a centrumállamok gyakorlatilag a perifériára, és a félperifériára exportálták a prekaritást a nyugati jóléti konszenzus idején, így a nemzetközi piacokra termelő üzemek dolgozóinak helyzete jóval bizonytalanabb volt, mint az ugyancsak a periférián múködő, de önfenntartásra, vagy a szúkebb földrajzi környezet piacára berendezkedett üzemek dolgozóinak munkakörülményei. Mivel Magyarország félperifériás pozícióval jellemezhető a globális munkamegosztásban, a hazai társadalomnak is egy - időben és összetételében változó - része a világgazdaság folyamatainak jobban kitett, prekárius helyzetű. A majorok vizsgálata során ennek a gondolatnak a szem előtt tartása rámutathat, hogy milyen nemzetközi trendek alakították ennek a településtípusnak, a bennük élő emberek helyzetét, illetve hogy a majorokban, a helyi léptéken jelentkező folyamatok hogyan helyezhetők globális kontextusba.

A második világháború előtt a nagybirtokokon dolgozók helyzetét nagyban befolyásolták a nemzetközi gazdasági trendek, így például az 1920-as évek válsága a termények világpiaci árának csökkenése miatt a mezőgazdasági munkások bérére, illetve a cselédek járandóságára is erősen hatott (Gunst P. 1970). Az önálló földtulajdonnal bíró parasztság kapcsolata ezzel a piaccal lazább volt, nem ritkán attól teljesen elkülönülten, önmaga, vagy szúkebb környezete ellátására termelt, így esetükben a nemzetközi gazdasági trendek csak hosszú távon (például a termelés intenzifikálásának kényszere) éreztették hatásukat, rövid távon elsősorban az időjárás befolyásolta az éves jövedelmüket. GUNST PÉTER (1998) a szegényebb paraszti rétegek és a cselédség jövedelmi viszonyainak összehasonlítása során arra mutatott rá, hogy a cselédek jövedelme esetenként magasabb is lehetett, mivel a kiszámíthatatlan terméseredmények a törpebirtokosokat sokkal jobban veszélyeztették, mint az éves szerződéssel rendelkező cselédeket. A cselédség jövedelmének bizonytalan elemét ugyanakkor a járandóság (konvenció, vagy kommenció) - amely főként terményekből és tüzelőből állt - összetétele képezte, amely uradalmanként is eltérő volt (EPERJESSY E. 2006), a munka és a megélhetés bizonytalansága tehát valamennyi mezőgazdaságból élő, szegényebb rétegre jellemző volt. A cselédség helyzetét a világrendszer-elméletek felől közelítve ugyanakkor arra következtethetünk, hogy a hazai agrárszektorban elfoglalt pozíciójuk mellett a globális munkamegosztásba való beágyazódásuk is speciális volt; 
nemzetközi pozíciójuk más félperifériás helyzetű országok prekárius társadalmi csoportjaihoz hasonlította őket.

A második világháborút követően Magyarországon a szovjet mintájú tervgazdálkodás kiépítése vált céllá, amely fokozatosan ment át államilag (egyre lazábban) szabályozott kapitalizmusba. Az ország formálisan nem állt kapcsolatban a világgazdaságnak a nyugati blokk által kontrollált részével, az új gazdasági és politikai centrum a Szovjetunió, a gazdasági csere fóruma pedig a KGST volt. Ennek ellenére a tôke és a technológia hiánya az 1960-as évektől egyre látványosabb nyugati transzfereket eredményezett (ÉBER M. Á. et al. 2014; PINKASz A.-GERőCS T. 2017). A mezőgazdaságban ennek egyik legemblematikusabb példája a Bábolnai Állami Gazdaság által végrehajtott termelésszervezési reform, az iparszerú termelési rendszerek létrehozása volt, amely intenzív nyugati gazdasági együttmúködések révén valósult meg. Ennek része volt például nyugatnémet-magyar közös vállalatok létrehozása, gépparkok, és egyéb termelőeszközök importja, illetve komplett üzemek - zömmel a globális periféria államaiba irányuló - exportja (IzINGER P. 1983; SCHLETT A. 2004). Mivel a modell egyre inkább elterjedt az állami gazdaságok körében, ezért a mezőgazdasági munkaeró helyzetére egyértelmúen hatást gyakorolt a nyugati tőke- és technológiaimport. Vagyis a majorokban élő - nagyobb részt állami gazdaságokban dolgozó, kisebb részt szövetkezeti paraszt - emberek egy olyan rendszer részei voltak, amely nagymértékben támaszkodott a nyugati kapitalista világgazdasággal fennálló egyre szorosabb kapcsolatra, amellett, hogy a megtermelt termények és termékek legfontosabb felvevője továbbra is a KGST maradt. Az állami gazdaságok szakmai és politikai önállóságának növekedése (IZINGER P. 1982, 1983) mellett is elmondható, hogy bár a vállalatok egyre inkább függtek a nemzetközi gazdasági környezet változásaitól, az egyének szintjén - munka és életkörülményeiben - inkább érvényesült a központi szabályozók hatása. Ez legfőképpen a stabil és kiszámítható munka tapasztalatában manifesztálódott. Ezzel együtt is kérdéses azonban, hogy mit kezdjünk a Kádár-korszakkal, mint potenciális, a nyugati jóléti állami időszakhoz hasonló referenciaponttal (SzÉPE A. 2016) - a majorok népességének vizsgálata során is fontos ennek a kérdésnek az eldöntése.

Az 1990-es évektől Magyarországon egyre erőteljesebben nyert teret a neoliberális gazdaságszemlélet, és egyre erősebbé vált a nyugati központú kapitalista világgazdasággal fennálló politikai és gazdasági kapcsolódás (függés) is, vagyis megváltozott az ország nemzetközi munkamegosztásban elfoglalt helyzete. A szocialista agrárüzemek magánosításával pedig a majorok népességének (globális)munkaerőpiacba való beágyazódása is megváltozott. Ennek a legfontosabb jellemzője az erőteljes differenciálódás: korábban a majorokban élők döntő része ugyanazt a pozíciót foglalta el a gazdasági termelésben (uradalmi cselédek, majd szocialista nagyüzemi mezógazdasági dolgozók voltak), a privatizációt követôen ez egyre jobban különválik az egyének szintjén. Az empirikus eredmények alapján az egykori nagyüzemi dolgozók jelentős részének munkaerópiaci helyzete a nehézipari munkássághoz hasonlóan megingott: a korai nyugdíjazás mellett a tartós munkanélküliség a majorokban is gyakori jelenség volt, az alacsony képzettségú fizikai munkaerôt igénylő munkahelyek hiánya tartósnak, az ilyen jellegú foglalkoztatáshoz szokott emberek alkalmazkodása az új elvárásokhoz pedig nehéznek bizonyult. Ezek alapján valószínúsíthető, hogy napjainkban a majorok a prekariátus egyik gyújtőhelyeként azonosíthatók, hiszen a hazai kontextusban prekárius élethelyzetú csoportok körülhatárolására tett kísérletekkel több ponton is egyezik a majorok társadalmáról kibontakozó kép. FERGE ZsUZSA (Fordulat 2012), és ÉBER MÁRK ÁRON (2016) több olyan csoportot, is megnevezett, akiket a hazai viszonyok között a prekariátushoz sorolhatunk, közülük több a majorokban is megtalálható (például: közmunkások, kényszervállalkozók, illegálisan munkát vállalók, szezonális mezőgazdasági munkát feketén végzők). 


\section{Összefoglalás}

Az újrastrukturálódás és a prekariátus koncepciója a majorok kutatásában két szempontból is tanulságos. Az első, hogy ezek a koncepciók lehetővé teszik a különböző léptékeken zajló folyamatok közötti összefüggések jobb megértését. Amíg a világrendszer-elméletek szempontjából elemzett prekaritás a majorbeli társadalmakat globális kontextusba helyezi, az újrastrukturálódás elsősorban az országos és a helyi léptékek között közvetít. A második tanulság, hogy mindkét koncepció lehetôvé teszi a hosszabb időtávú vizsgálódást, a szakaszhatárok, és folytonosságok meghatározhatóságát. Az újrastrukturálódás három dimenziójának (az állam, a gazdaság és a civil társadalom) módszeres vizsgálata megmutatja, hogy a különböző szférákban végbement változások időben hogyan válnak el egymástól, illetve mikor mekkora mértékben alakítják egymást. A prekariátus fogalma pedig arra világít rá, hogy a munkakörülmények, vagyis a munkaadók globális beágyazottsága időben mennyire változó, vagy állandó.

A fenti elemzés alapján az látszik, hogy a globális politikai-gazdasági trendek és az országos léptéken érzékelhető társadalmi folyamatok a majorokban a 20. század folyamán sok szempontból speciális élethelyzeteket eredményeztek. A századelőn a falvaktól elkülönült, a nemzetközi agrárpiactól jobban függő uradalmi cselédség volt jelen. Az 1950-es évektől az elkülönülés részben oldódott, a szocialista nagyüzemek dolgozóiként a szociális jogok bővülése kiterjedt a majorban élőkre is, bár a falvakra jellemzónél erősebb volt az üzem szerepe a helyi folyamatok alakításában. A rendszerváltás után a majorok sok esetben a községek szegregátumaivá válnak, és ismét a társadalmi távolság növekedése figyelhetô meg, vagyis a globálisan növekvő társadalmi különbségek itt a leszakadó csoportok növekvő térnyerésében öltenek testet. A majorok tehát történeti távlatban is a prekariátus potenciális gyưjtőhelyeinek tűnnek, azonban a települési szintú, illetve a településen belüli, háztartási szintű differenciálódás is jellemző folyamat, amely megnehezíti a majorbeliek ilyenfajta címkézését.

Amennyiben az elmúlt száz évben lezajlott folyamatokat a HogGarT, K. és PANIAGUA, A. (2001a, 2001b) által hangsúlyozott szempontok mentén szeretnénk elemezni, kirajzolódik, hogy a különböző dimenziók eltérő ütemben változtak. Az állam szerepének változása egybeesik az általánosan alkalmazott politikatörténeti szakaszolással: a két világháború közötti időszak, az államszocializmus, illetve a rendszerváltás utáni Magyarország elkülönítése a majorok esetén is releváns. A helyi állam szerepének változásai ugyanakkor a majorokban másként csapódtak le, mint a belterületeken, hiszen a tanácsi rendszer létrejöttével is a helyi üzemtől függött a major sorsa. Érdemi változás az önálló önkormányzatok szervezésével következett be, amely a majorokban általában „gazdátlanságot” eredményezett. A gazdasági környezet változásai ezekkel az átmenetekkel összefüggnek ugyan, de némileg eltolódva jelentkeznek, ami a majorok esetén is megfigyelhető: az 1960-as évektől meginduló termelésszervezési reformok a majorokat is érintették, azonban a különböző gazdasági szektorok súlya a majorokban sokkal kevésbé változott az államszocializmus idején, mint országosan. Markáns átalakulást hoztak viszont az 1990-es évek, amikor a korábbi gazdasági tevékenységek leépülése vált általánossá a majorokban. A helyi társadalom átalakulása tekintetében ugyancsak az 1960-as 1970-es évek, valamint a több hullámban történő privatizáció tekinthető választóvonalnak. A három dimenzió mentén elkülöníthető folyamatokat egybevetve az 1960-as, 1970-es évekre a korábbi korszakhoz képest nagyban különböző helyzet alakult ki a majorok többségében, azonban markáns és egyértelmú újrastrukturálódás az 1990-es, 2000-es években zajlott le. A majorokat kezelő, üzemeltető, és a helyieknek munkát adó szereplők globális beágyazottsága is sok tekin- 
tetben hasonló volt az uradalmi, és a szocialista nagyüzemi idốszakban. A privatizációt követốen a majorban élốk zömmel a településen kívül vállalnak munkát, vagyis diverzifikálódik a népesség munkaerőpiaci pozíciója. A rendelkezésre álló szakirodalmak alapján felvázolt képet ugyanakkor árnyalni szükséges. A tanulmányom elején említett célhoz - a helyi és a többi léptéken zajló folyamatok összekötése - közelebb vihet az itt bemutatott általános jellemzés mellett a helyi viszonyok átalakulásának esettanulmányokon keresztül történố vizsgálata.

\title{
Köszönetnyilvánítás
}

Köszönöm CZIRFuSz MÁRTON, NÉMETH KRISZTINA és TIMÁR JudiT szakmai tanácsait és javaslatait.

\author{
MIKLE GYÖRGY \\ ELTE TTK Társadalom- és Gazdaságföldrajzi Tanszék, Budapest \\ miklegyo@gmail.com
}

\section{IRODALOM}

BAjMócy P.-Pócsi G. -JózSA K. 2008: A majorságok településföldrajzi fejlôdése és jelenlegi differenciálódása Somogy megye példáján. -In: SZABO V.-OrosZZ.-NAGY R. -FAZEKAS I. (szerk.): IV. Magyar Földrajzi Konferencia, Debreceni Egyetem, Debrecen. pp. 322-327.

BAjMócy P.-BALOGH A. 2012: Egykori majorok tipizálása Vas megyei példákon. - Földrajzi Közlemények 136. 2.pp. 165-181.

BAJMÓCY P.-MAKRA Zs. 2016: Központi-, egyéb belterületek és külterületek népesedési trendjei Magyarországon 1960-2011 között. - Településföldrajzi tanulmányok 5. 2. pp. 3-21.

BAJMócy P. - MAKRA Zs.-TóTH L. 2018: A hazai külterületek átalakulása 1990 után. - Településföldrajzi tanulmányok 7. 1. pp. 3-17.

BALOGH A. 2016: Népességvesztô külterületek eltérô társadalmi folyamatai Vas megyében. - Vasi szemle 70. 6. pp. 735-744.

BALOGH A. 2012: A külterületek településföldrajzi vonatkozásai. - A Nyugat-magyarországi Egyetem Savaria Egyetemi Központ tudományos közleményei, 19. Természettudományok 14. pp. 127-138.

BALOGH A.-BAjmócy P. 2011: Majorok a Nyugat-Dunántúlon. - Savaria University Press, Szombathely. 126 p.

BALOGH A.-BAJMócy P. 2014: Elnéptelenedố külterületek. - Településföldrajzi tanulmányok 3.3. pp. 59-69.

Beluszky P. 1999: Magyarország településföldrajza: Általános rész. - Dialóg Campus, Budapest-Pécs. 584 p.

BEREND T. I.-RÁNKı GY. 1976: Közép-Kelet Európa gazdasági fejlôdése a 19-20. században. - Közgazdasági és Jogi Kvk., Budapest. 723 p.

BÖCSKEI B.-SzÉPE A. 2012: Szabadság csak ott van, ahol nincs prekariátus! - bevezetố a Forđulat 19. számához. - Fordulat 5. 19. pp. 4-7.

Cloke, P. 1989: Rural geography and political economy. - In: PEet, R.-Thrift, N. (eds.): New Models in Geography: The Political Economy Perspective, Vol.1. Unwin Hyman, London. pp. 164-197.

Cloke, P.-Goodwin, M. 1992: Conceptualizing Countryside Change: From Post-Fordism to Rural Structured Coherence. - Transactions of the Institute of British Geographers 17.3, pp. 321-336.

Cloke, P. - Thrift, N. 1987: Intra-Class Conflict in Rural Areas. - Journal of Rural Studies 3. 1. pp. 311 -333.

CzIRFuSz M. 2017: A gazdaságföldrajz elméletei gazdaságról és térrôl - tanulságok a gazdaságföldrajz oktatásához. - Földrajzi közlemények 141.3. pp. 192-202.

CzIRFusz M.-PÓSFAI I.-Pósfal Zs. 2018: A lakhatási szegénység területi folyamatai. In: Pósfai Zs. -JELINEK Cs. -CzIRfusz M. (szerk.): Éves jelentés a lakhatási szegénységrốl 2018. - Habitat for Humanity Magyarország, Budapest.

CsOóRI S. 1963: Puszta az orgonásdomb alatt. - In: CsoóRI S.: Tudósítás a toronyból. Magvető Könyvkiadó, Budapest. pp. 5-35.

ÉBER M. Á. 2014: A centrum hitele: A magyar állam külsố eladósodásának történetérôl. - Fordulat 6. 21. pp. 64-86. 
ÉBER M. Á. 2015: Osztályszerkezet Magyarországon: A világrendszer-elemzés perspektívájából. - Replika 3-4, pp. 119-140.

ÉBER M. Á. 2016: Alacsony fizetés, bizonytalan munka, a létbiztonság hiánya: A prekárius élethelyzet terjedése és a bővülő prekariátus. - Új Egyenlítő 6. 11-12, pp. 5-9.

ÉBER M. Á. 2018: Ami kinn, az van benn. A „magyar társadalom” külső függőségeinek és belső szerkezeteinek viszonyáról. - socio.hu 8.2,pp. 119-134.

Éber M. Á.-Gagyi Á.-Gerốcs T.-Jelinek Cs.-Pinkasz A. 2014: 1989: Szempontok a rendszerváltás globális politikai gazdaságtanához. - Fordulat 6. 21, pp. 10-63.

EPERJESSY E. 2006: Puszták népe a Zselicben (1900-1950). - Mikszáth Kiadó, Horpács. 698 p.

ERDEI F. 1940: Magyar falu. - Reprint, 1974, Akadémiai kiadó, Budapest. 246 p.

ERDEI F. 1984: A mezőgazdasági népesség társadalmi-gazdasági viszonyainak alakulása a felszabadulás után. - In: ERdEI F. (szerk.): Történelem és társadalomkutatás. Akadémiai Kiadó, Budapest. pp. 201-241.

FARKAS X. 2015: A prekariátus fogalmának és magyarországi alkalmazhatóságának vizsgálata.-Szakdolgozat, ELTE-TÁTK Mesterképzés, Budapest. 73 p.

FÉJA G. 1938: Viharsarok: az Alsó-Tiszavidék földje és népe. - Athenaeum Kiadó, Budapest. 275 p.

Fordulat 2012: Beszélgetés Ferge Zsuzsával - Prekariátus és Magyarország. - Fordulat 5. 19. pp. 116-126.

Gunst P. 1970: A mezőgazdasági termelés története Magyarországon (1920-1938). - Akadémiai Kiadó, Budapest. 499 p.

GUNST P. 1998: A Magyar agrártársadalom a jobbágyság felszabadításától napjainkig. - Napvilág kiadó, Budapest. 437 p.

GYÁNI G.-KÖvÉR GY. 2004: Magyarország társadalomtörténete: A reformkortól a második világháborúig. - Osiris, Budapest. 395 p.

GYőRI R.-GyURIS F. 2015: Knowledge and Power in Sovietized Hungarian Geography. In: MeusburgER, P.-GREGORY, D.-SuArsana, L. (eds.): Geographies of Knowledge and Power. Springer, Dordrecht. pp. $203-233$.

HAJdú Z. 1990/1991: A Tanyai Tanács története (A „szocialista tanyapolitika” alapvetése és a tanyakérdés megoldásának radikális, voluntarisztikus kísérlete, 1949-1954). - Alföld Tanulmányok 14. pp. 105-124.

HAJDÚ Z. 1992: Település- és településhálózat- fejlesztési politika Magyarországon az államszocializmus idōszakában. - Földrajzi közlemények 40. 1-2. pp. 29-38.

Hann, C. 2003: The postsocialist agrarian question: Property relations and the rural condition. - Lit., Münster - London. 472 p.

Hoggart, K.-Paniagua, A. 2001a: What rural restructuring? - Journal of Rural Studies 17. 1, pp. 41-62.

Hoggart, K.-Paniagua, A. 2001b: The restructuring of rural Spain? - Journal of Rural Studies 17. 1, pp. 63-80.

HoRvÁth Cs. 2015: Növekvő népességû majorsági területek Veszprém megyében. - A falu 30. 2. pp. 35-45.

ILlYÉs Gy. 1936: Puszták népe. - Reprint, 1993 Századvég, Budapest. 218 p.

IZINGER P. 1981: Az első évtized: Az állami gazdaságok 1945-1956 között. - Valóság 6. pp. 26 -40.

IZINGER P. 1982: A második évtized: Az állami gazdaságok 1958-1968 között. - Valóság 5. pp. 36-51.

IzINGER P. 1983: A harmadik évtized. Az állami gazdaságok 1968-1980 között. - Valóság 3. pp. 38-45.

JUHÁSz P. 1999: Mai képünk a parasztságról s a falusi társadalom néhány jellegzetességéről. - In: FoKASz N.-ÖRKÉNY A. (szerk.): Magyarország társadalomtörténete III/2.: 1945-1989: válogatott tanulmányok. Új Mandátum Könyvkiadó, Budapest. pp. 230-240.

JuHÁsz P. 2006: Emberek és intézmények: Két zsákutca az agráriumban. - Új Mandátum Kiadó - Jelenkutató Alapítvány, Budapest. 617 p.

KARDOS L. 1955: Jegyzetek a volt uradalmi cselédség kultúrájának és életmódjának alakulásáról (Szentgyörgypuszta). - Ethnographia pp. 225-344.

KeLEMEN Zs.-RAKovics M. 2013: Prekaritás és habitus. Kérdések a prekariátusról, mint új osztályról és kategóriáról, Pierre Bourdieu társadalomelméletének tükrében. - In: BEZSENYI T.-DEMETER E.-HorZSA G.-MEIXNER B.-PEtÉNYi S.-SzeKeres B. (szerk.): Kötetlen. Az ELTE Angelusz Róbert Társadalomtudományi Szakkollégium tanulmánykötete. ELTE ARTSZ, Budapest. pp. 13-22.

KLENCZNER A. 1996: Az állami gazdaságokról. - In: Orosz I.-Für L.-RoMÁNY P. (szerk.): Magyarország agrártörténete. Mezőgazda Kiadó, Budapest. pp. 697-698.

KovÁCH I. 2012: Vidék az ezredfordulón. A jelenkori magyar vidéki társadalom szervezeti és hatalmi változásai. - Argumentum, Budapest. 244 p.

KovÁcs É.-VIDRA Zs. 2012: Kényszer, vagy kivonulás - élet a peremeken. - Tér és Társadalom 26. 4. pp. 73-92.

LAmPLAND, M. 2016: The Value of Labor: The Science of Commodification in Hungary, 1920-1956. - The University of Chicago Press, Chicago - London. 330 p.

LAVAQUE-MAnTY, M. 2012: Hogy bukkanhatunk elméleti fogalmakra a való világban? A prekariátus esete. (Fordította: LATORRE Á.) - Fordulat 5. 19. pp. 52-74.

LENGYEL Zs. 1981: Néhány gondolat a szövetkezetek és a falvak kapcsolatáról. - In: VASs H. (szerk.): A mezőgazdaság szocialista átalakulása Magyarországon: Tudományos ülésszak Túrkeve 1981.április 6-7. Szolnok Megyei Lapkiadó Váll., Szolnok. pp. 166-171. 
MARSDEN, T. 1996: Rural geography trend report: the social and political bases of rural restructuring. - Progress in Human Geography 20. pp. 246-258.

Marsden, T.-Munton, R.-Whatmore, S.-Little, J. 1986: Towards a political economy of capitalist agriculture: a British perspective. - International Journal of Urban and Regional Research 10. pp. 498-521.

MasinKa K. 2018: A magyar településhálózat hagyományos elemei - külterületek vizsgálata és tipizálása a Dél-Dunántúlon. - Településföldrajzi tanulmányok 7.2.pp. 18-30.

MÁtyus A.-TAusz K. 1984: Maga-ura parasztok és uradalmi cselédek: szociográfia. - Magvető, Budapest. 217 p.

MENDÖL T. 1963: Általános településföldrajz. - Akadémiai Kiadó, Budapest. 567 p.

MikLE Gy. 2015: A majorok helyzetének változásai Bábolna és Mezőhegyes példáján. - Településföldrajzi tanulmányok 4. 2. pp. 44-54.

MolnÁR I.-SzaBÓNÉ MedGYesi É. 1987: Állami Gazdaságok Magyarországon.-Mezőgazdasági kiadó, Budapest. 416 p.

Németh K. 2013: „Koszos lóra bársony nyereg nem illik.” Cselédek és urak - egykor és most. - Belvedere meridionale 25. 3, pp. 31-50.

NÉMETH K. 2015: „A puszta le van robbanva.”: helykötődés és nosztalgia a pusztai élettörténetekben. - In: KESZEI A.-BöGRE Zs. (szerk.): Hely, identitás, emlékezet. L’Harmattan Kiadó, Budapest. pp. 356-379.

NÉMETH K. 2016: Mobilitási utak egy mezőgazdasági nagyüzem dicsfényében és árnyékában. - In: KovÁCs K. (szerk.): Földből élők: Polarizáció a magyar vidéken. Argumentum Kiadó, Budapest. pp. 162-185.

PINKASZ A.-GERŐCs T. 2017: A KGST a világrendszerben. Egy félperifériás kísérlet gazdaságtörténeti elemzése. - Eszmélet 29. 113. pp. 15-36.

PóSFAI Zs. 2018: Reproducing uneven development on the Hungarian housing market. - Doktori értekezés, Szegedi Tudományegyetem, Földtudományok Doktori Iskola, Szeged. 142 p.

Schlett A. 2004: Innováció a szocializmusban: A Bábolnai Állami Gazdaság története 1960 és 1991 között. - Doktori értekezés, Pázmány Péter Katolikus Egyetem, BTK, Budapest. 213 p.

SiK E.-TAusz K. 1978: Az uradalmi cselédek és a földosztás. - Szociológiai Füzetek 15. pp. 15-43.

SisKÁNÉ SzILASI B.-HALÁsz L. 2017: Globális munkaerőpiaci kihívások az új gazdaságföldrajzi folyamatok tükrében. - Földrajzi közlemények 141. 3. pp. 263-274.

STANDING, G. 2012: Prekariátus: Lakosokból állampolgárok (Fordította: LATORRE Á.) - Fordulat 5. 19. pp. 28 -51.

SzÉPE A. 2012: Prekariátus: Miért pont most és miért pont itt? - Fordulat 5. 19. pp. 10-27.

SzÉPE A. 2016: Prekariátus: az új alsó osztály? A prekariátus fogalmának kialakulása és egy lehetséges újragondolása. - Doktori értekezés, ELTE TÁTK, Budapest. 141 p.

TAMÁSKA M. 2013: Falvak az uradalmak helyén: a megszűnt nagybirtok telepes községeinek építészete 1945 után. - Martin Opitz Kiadó, Budapest. 240 p.

ThrifT, N. 1987: Manufacturing rural geography. - Journal of Rural Studies 3. pp. 77-81.

TIMÁR J. 2016: A falusiak államhoz való viszonyának megjelenítése eltérő szemléletű földrajzi kutatásokban. - In: Sikos T. T.-Tiner T. (szerk.): Tájak, régiók, települések térben és időben: tanulmánykötet Beluszky Pál 80. születésnapjára. Dialóg Campus Kiadó, Budapest. pp. 429-438.

VARGA D. 1991: Mai puszták népe: volt cselédek, mai gondok Dél-Dunántúl állami gazdasági pusztáin. - Baranya megyei könyvtár, Pécs. 265 p.

VARGA Zs. 2011: Between East and West: a cultic place of the Hungarian agriculture - Bábolna Farm. - In: Halmesvirta, A. (ed.) Cultic Revelations: Cult Personalities and Phenomena. University of Jyväskylä, Faculty Of Humanities, Department of Art and Culture Studies, Hungarian Studies, Jyväskylä. pp. 161-180.

VASÁRUS G. 2016: Külterületi szuburbanizáció és szegregáció - példák vidéki agglomerációk konfliktusaira. - Településföldrajzi tanulmányok 5. 1.pp. 84-94.

VIGVÁRI A. 2015: Vissza a tanyákra: egy cigány család újrakezdési esélyei a szabolcsi pusztai világban. - In: VIRÁG T. (szerk.): Törésvonalak: Szegénység és etnicitás vidéki terekben. Argumentum, Budapest. pp. 211-229.

VIRÁG T. 2015: Szegénysors: mindennapok egy pusztán. - In: VIRÁG T. (szerk.): Törésvonalak: Szegénység és etnicitás vidéki terekben. Argumentum, Budapest. pp. 229-246.

WACQUANT, L. 2011: Lakóhely szerinti megbélyegzés a fejlett marginalitás korában. (Fordította: DósA M.) - Fordulat 4. 13. pp. 14-27.

Woods, M. 2005: Rural Geography: Processes, Responses and Experiences in Rural Restructuring. - SAGE, London - Thousand Oaks - New Delhi. 336 p.

Woods, M. 2009: Rural geography: blurring boundaries and making connections. - Progress in Human Geography 33. 6. pp. 849-858. 